\author{
Andrzej SZLĘK ${ }^{1}$ \\ Michał CHABIŃSKI ${ }^{2}$
}

\title{
WPEYW WILGOTNOŚCI BIOMASY NA SPRAWNOŚĆ UKŁADU KOTŁA TERMALNEGO WSPÓŁPRACUJĄCEGO Z MODUŁEM ORC
}

\begin{abstract}
Kotły opalane biomasą współpracujące $\mathrm{z}$ modułami ORC stanowią technologię często wykorzystywana do generacji energii elektrycznej w małej skali. Układy takie zasilane są przy tym biomasą pochodzenia lokalnego, co najczęściej wiąże się ze zmienną jakością biomasy, w tym przede wszystkim ze zmienną wilgotnością. Jednocześnie spaliny za wymiennikiem ciepła służącym podgrzaniu oleju termalnego mają temperaturę pozwalającą na ich wykorzystanie do podgrzania powietrza do spalania lub do podgrzania powietrza suszarniczego. W niniejszej pracy przeanalizowano skutki energetyczne jakie wiążą się z wykorzystaniem energii spalin do podgrzania powietrza służącego wstępnemu suszeniu biomasy.
\end{abstract}

Słowa kluczowe: technologia ORC, spalanie biomasy

\section{Wprowadzenie i cel pracy}

\subsection{Układy kogeneracyjne małej mocy zasilane biomasą}

Do generacji energii elektrycznej i ciepła w układach małej mocy możliwe jest zastosowanie takich technologii jak: obieg parowy związku organicznego (ORC) zasilany gorącym czynnikiem produkowanym w kotle opalanym biomasą, zgazowarkę produkującą gaz palny spalany następnie w silniku spalinowym tłokowym lub turbinowym, silnik Stirlinga zasilany ciepłem pobieranym bezpośrednio od spalin lub układ turbiny powietrznej zasilany ciepłem pobieranym od spalin $[1,2,3]$. Ostatnie dwie technologie jakkolwiek opanowane technicznie charakteryzują się bardzo wysokimi kosztami inwestycyjnymi [4].

Silnik spalinowy zasilany gazem ze zgazowarki charakteryzuje się najlepszą sprawnością produkcji energii elektrycznej, ale wciąż nierozwiązanym po-

\footnotetext{
${ }^{1}$ Autor do korespondencji: Andrzej Szlęk, Politechnika Śląska, ul. Konarskiego 22, 44-100 Gliwice, tel. 322371041 , andrzej.szlek@polsl.pl

2 Michał Chabiński, Politechnika Śląska, ul. Konarskiego 22, 44-100 Gliwice, michal.chabinski@polsl.pl
} 
zostaje problem oczyszczania gazu ze smół powstających w procesie zgazowania [5][6]. W tej sytuacji najwięcej realizacji przemysłowych opiera się na obiegach ORC zasilanych olejem termalnym podgrzewanym w kotle opalanym biomasą. Układy takie instalowane są w zakładach przemysłowych, w których jednocześnie występuje strumień odpadowej biomasy oraz zapotrzebowanie na ciepło (na przykład w tartakach), oraz w centralnych źródła ciepła miejskiej sieci ciepłowniczej, przy czym ciepło produkowane w układzie służy pokryciu potrzeb przygotowania ciepłej wody użytkowej [7].

Bardzo istotnym czynnikiem, który musi zostać uwzględniony na etapie inwestycji jest wilgotność biomasy. Od tego parametru zależy nie tylko sprawność energetyczna układu ale również konstrukcja samego paleniska. Obecnie producenci oferują paleniska mogące być zasilane biomasą o wilgotności na poziomie $60 \%$ [8].

\subsection{Temperatura spalin $w$ kotłach współpracujących $\mathrm{z}$ modułami ORC}

W kotłach współpracujących z modułami ORC podgrzewany olej termalny, na dolocie do kotła ma temperaturę rzędu $300^{\circ} \mathrm{C}$ [9]. Spaliny za wymiennikiem mają temperaturę wyższą i dla zapewnienia wysokiej sprawności energetycznej urządzenia konieczne jest wykorzystanie entalpii spalin. Możliwe jest przy tym podgrzanie powietrza spalania lub podgrzanie powietrza suszarniczego wykorzystanego następnie do wstępnego suszenia biomasy podawanej do kotła. Dodatkowo, przy spalaniu biomasy o wysokiej wilgotności spaliny zawierają znaczące ilości pary wodnej, co czyni atrakcyjnym energetycznie schładzanie spalin do temperatury, w której możliwe staje się wykorzystanie entalpii parowania wody.

\subsection{Cel pracy}

Celem niniejszej pracy jest określenie w jaki sposób można wykorzystać entalpię spalin za wymiennikiem podgrzewającym olej termalny do osiągnięcia maksymalnej sprawności energetycznej układu złożonego z kotła i modułu ORC. Analizę przeprowadzono dla biomasy o rożnej wilgotności, biorąc pod uwagę różne poziomy temperatury wylotowej spalin.

\section{Opis przeprowadzonej analizy}

\subsection{Opis analizowanego obiektu}

Na rysunku 1 przedstawiono schematycznie analizowany obiekt. Składa się on z suszarki (zasilanej powietrzem suszarniczym) służącej do wstępnego suszenia biomasy, komory spalania, wymiennika ciepła podgrzewającego olej termalny, podgrzewacza powietrza do spalania oraz podgrzewacza powietrza suszarniczego. 


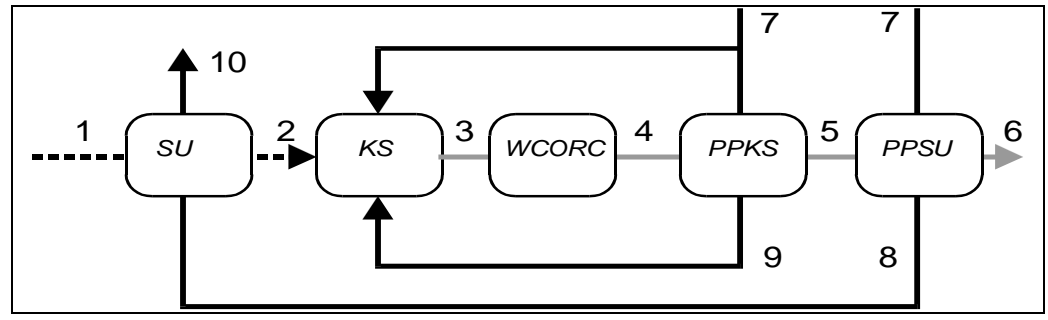

Rys. 1. Schemat analizowanego układu. SU-suszarka, KS-komora spalania, WCORC - wymiennik ciepła podgrzewający olej termalny, PPKS-podgrzewacz powietrza do spalania, PPSU-podgrzewacz powietrza suszarniczego

Fig. 1. Scheme of the analysed system. SU-drier, KS-combustion chamber, WCORC - heat exchanger heating thermal oil, PPKS-combustion air preheater, PPSU-drying air preheater

Powietrze z otoczenia 7 podawane jest częściowo do podgrzewacza zasilającego komorę spalania, częściowo wprost do komory spalania, a częściowo do podgrzewacza powietrza suszarniczego. Biomasa 1 podawana jest do suszarni a następnie do komory spalania, gdzie ulega całkowitemu i zupełnemu spaleniu. Powstałe spaliny 3 ochładzają się w wymienniku ciepła WCORC oddając ciepło do oleju termalnego zasilającego moduł ORC, następnie w wymienniku podgrzewającym powietrze do spalania, a ostatecznie $\mathrm{w}$ wymienniku podgrzewającym powietrze suszarnicze.

\subsection{Przyjęte założenia}

W celu realizacji obliczeń poczyniono założenia odnośnie każdego z urządzeń wchodzących w skład układu przedstawionego na rysunku 1 . W przypadku suszarni założono, że jest ona jednostopniowa, a powietrze opuszczające suszarnię znajduje się w stanie nasycenia i nie zawiera wykroplonej wilgoci. Straty ciepła do otoczenia z urządzenia zostały pominięte. Założenia te pozwoliły na określenie strumienia powietrza niezbędnego do osiągnięcia założonego zmniejszenia wilgotności biomasy.

W komorze spalania założono spalanie zupełne i całkowite oraz brak strat ciepła do otoczenia, co przy znanych strumieniach substratów na dolocie do komory pozwoliło na określenie składu i temperatury spalin na wylocie w punkcie 3 (Rys. 1). Wymienniki ciepła służące do podgrzewania oleju termalnego, powietrza suszarniczego oraz powietrza spalania potraktowano jako doskonale zaizolowane, co przy założeniu temperatur spalin na wylocie z wymiennika ciepła WCORC oraz na wylocie $\mathrm{z}$ układu pozwoliło na określenie temperatury spalin $\mathrm{w}$ punkcie 5 oraz temperatury powietrza do spalania $\mathrm{w}$ punkcie 9. Założono ponadto, że spaliny za wymiennikiem WCORC mają tem- 
peraturę równą $\mathrm{t}=350^{\circ} \mathrm{C}$, co jest wartością wystarczającą dla zapewnienia efektywnego przekazywania ciepła do oleju zasilającego moduł ORC.

Obliczenia przeprowadzane były iteracyjnie, ze względu na wzajemny wpływ temperatury spalin za komorą spalania na temperaturę powietrza spalania.

\section{Wyniki obliczeń}

\subsection{Wpływ wilgotności na temperaturę adiabatyczną spalania}

W pierwszej kolejności przeprowadzono obliczenia temperatury adiabatycznej spalania w zależności od stosunku nadmiaru powietrza oraz wilgotności biomasy. Obliczenia te miały na celu określenie zakresu zmian wymienionych parametrów przy których temperatura spalin jest na tyle wysoka, że umożliwia dopalenie węglowodorów powstałych w procesie termicznej konwersji biomasy. Wyniki obliczeń przedstawia rysunek 2.

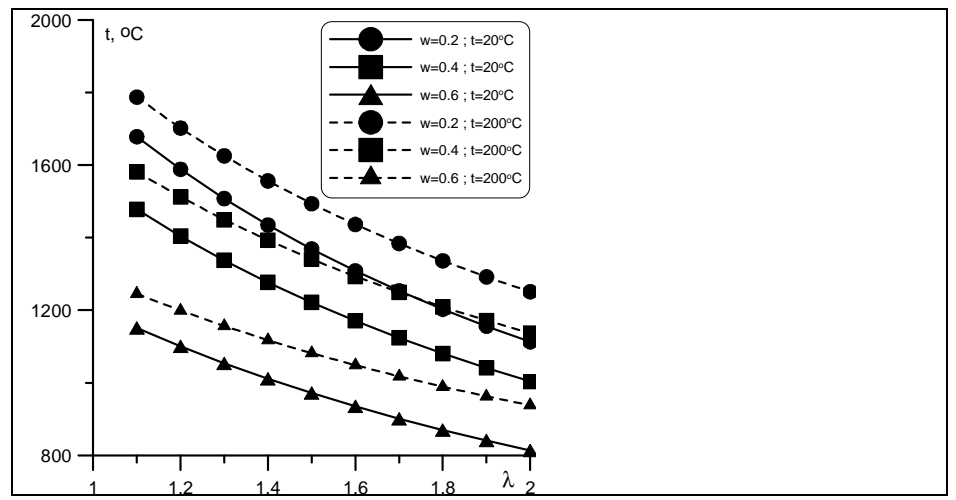

Rys. 2. Temperatura adiabatyczna spalania jako funkcja stosunku nadmiaru powietrza dla różnych wilgotności (w) biomasy i dwóch temperatur powietrza spalania $(\mathrm{t})$

Fig. 2. Adiabatic combustion temperature as a function of air excess ratio for various biomass water content $(w)$ and two combustion air temperatures $(\mathrm{t})$

Jak można wnioskować $\mathrm{z}$ danych przedstawionych narysunku 2 w przypadku wysokiej wilgotności biomasy i wysokich stosunków nadmiaru powietrza, temperatura spalania jest niższa od $1000^{\circ} \mathrm{C}$. Stwarza to niebezpieczeństwo niedopalenia węglowodorów pochodzących z termicznego rozkładu substancji organicznej biomasy. $\mathrm{Z}$ tego względu w obliczeniach przeprowadzonych $\mathrm{w}$ dalszej części pracy kontrolowano temperaturę za komorą spalania uznając przypadki, w których osiągała ona wartości poniżej $1000^{\circ} \mathrm{C}$ za nieakceptowalne ze względu na emisję produktów niezupełnego spalania. 


\subsection{Obliczenia wielowariantowe}

W tym etapie pracy przeprowadzono obliczenia wpływu wilgotności biomasy za suszarnią, stosunku nadmiaru powietrza oraz temperatury końcowej spalin na sprawność układu rozumianą jako ciepło przekazane do modułu ORC odniesione do energii chemicznej biomasy wyrażonej poprzez wartość opałową. Wyniki tych obliczeń przedstawione zostały na rysunku 3.

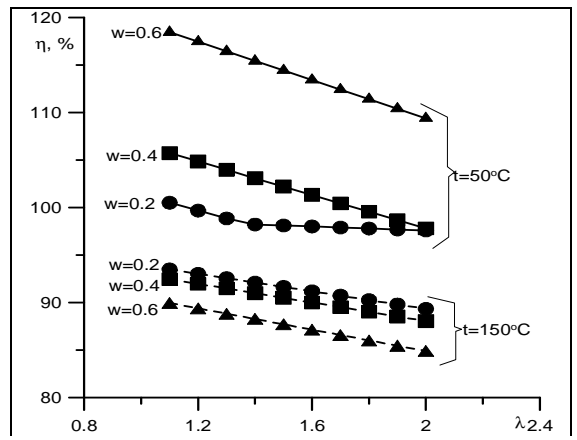

Rys. 3 Sprawność układu jako funkcja stosunku nadmiaru powietrza dla dwóch różnych temperatur końcowych spalin (t) i trzech różnych wilgotności biomasy za suszarnią (w)

Fig. 3. Efficiency of the system as a function of the air excess ratio for two different flue gas final temperatures $(\mathrm{t})$ and three various moisture content in biomass (w)

Jedna rodzina krzywych przedstawionych na rysunku 3 związana jest $\mathrm{z}$ temperaturą końcową spalin równą $50^{\circ} \mathrm{C}$ co odpowiada sytuacji, w której końcowy wymiennik ciepła schładzający spaliny schładza je do temperatur niższych lub porównywalnych z temperaturą rosienia spalin. Druga rodzina krzywych odpowiada sytuacji w której nie dopuszcza się do kondensacji pary wodnej zawartej w spalinach poprzez utrzymanie końcowej temperatury spalin równej $150^{\circ} \mathrm{C}$

We wszystkich przypadkach przedstawionych na rysunku 3 założono, że początkowa wilgotność biomasy przed suszarnią wynosi 60\%. Przyjęto również, że temperatura i wilgotność względna powietrza atmosferycznego wynoszą odpowiednio $15^{\circ} \mathrm{C}$ oraz $60 \%$.

$\mathrm{W}$ przypadku odpowiadającym temperaturze końcowej spalin równej $50^{\circ} \mathrm{C}$ uzyskane wartości sprawności przekraczają $100 \%$ co wynika z odnoszenia sprawności do wartości opałowej przy jednoczesnej kondensacji pary wodnej powstałej w wyniku spalania. Można również zauważyć, że w przypadku wilgotności $\mathrm{w}=20 \%$ następuje załamanie krzywej co odpowiada początkowi procesu kondensacji pary wodnej w spalinach.

$\mathrm{W}$ przypadku końcowej temperatury spalin równej $150^{\circ} \mathrm{C}$ krzywe układają się poniżej sprawności $100 \%$, a ich przebieg pozbawiony jest załamań. Nachylenie krzywych jest przy tym mniejsze niż w przypadku temperatury spalin równej $50^{\circ} \mathrm{C}$.

Najciekawszym spostrzeżeniem wynikającym z analizy rysunku 3 jest fakt, że zwiększenie wilgotności biomasy za suszarnią wpływa korzystnie na sprawność w przypadku końcowej temperatury spalin równej $50^{\circ} \mathrm{C}$, a niekorzystnie w przypadku temperatury końcowej równej $150^{\circ} \mathrm{C}$. Oznacza to, że jeśli układ wy- 
posażony jest $\mathrm{w}$ wymienniki ciepła powodujące kondensację pary wodnej $\mathrm{w}$ spalinach, z termodynamicznego punktu widzenia nie jest korzystnym wstępne suszenie biomasy. Korzystniejszym jest natomiast pełne wykorzystanie entalpii spalin za wymiennikiem zasilającym moduł ORC do podgrzania powietrza spalania. Wynika to oczywiście z przyjętych założeń w myśl których woda zawarta w biomasie opuszcza układ w postaci gazowej, jeżeli zostanie odparowana w suszarni, natomiast w postaci ciekłej jeżeli trafi do spalin, a następnie zostanie skondensowana. Przyjęte założenia wynikają z możliwych do zastosowania rozwiązań konstrukcyjnych, dlatego wniosek ten ma znaczenie aplikacyjne.

Wpływ wilgotności biomasy na sprawność układu w przypadku temperatury końcowej spalin równej $150^{\circ} \mathrm{C}$ nie jest znaczny, a po uwzględnieniu strat ciepła w suszarni dodatkowo uległby zmniejszeniu. W tym przypadku instalowanie wstępnych suszarni biomasy również nie wydaje się wskazane.

\section{Podsumowanie}

Przedstawione rozważania dotyczą prostego układu kotła opalanego biomasą mokrą współpracującego ze wstępną suszarką biomasy oraz modułem ORC. Wielowariantowe obliczenia, przeprowadzone na podstawie założeń przyjętych z uwzględnieniem technicznych możliwości budowy układu wskazują, że w przypadku zastosowania wymienników pozwalających na kondensację pary wodnej nie jest korzystnym termodynamicznie wstępne suszenie biomasy. Także w przypadku temperatury spalin przekraczającej temperaturę kondensacji pary wodnej wpływ wilgotności biomasy przed komorą spalania jest na tyle niewielki, że nie uzasadnia instalowania suszarni.

Oczywiście powyżej pewnej wilgotności biomasy budowa paleniska umożliwiającego jej spalanie jest bardzo trudna lub wręcz niemożliwa, zatem zastosowana suszarnia wstępna powinna sprowadzić wilgotność biomasy do takiego poziomu, który umożliwia jej spalanie w palenisku.

Zarówno w przypadku kondensacji pary wodnej w spalinach jak i w przypadku w którym para wodna nie ulega kondensacji, korzystnym jest utrzymywanie niskiego stosunku nadmiaru powietrza. W przypadku schładzania spalin poniżej temperatury kondensacji wzrost sprawności powodowany jest przez większe ciśnienie cząstkowe pary wodnej w spalinach, a tym samym większą jednostkową ilość wykroplonej pary wodnej przy danej temperaturze schłodzenia spalin. W przypadku temperatury spalin przekraczającej temperaturę kondensacji stosunek nadmiaru powietrza wpływa na sprawność wyłącznie poprzez zwiększenie jednostkowej masy spalin wyprowadzanej z układu. 


\title{
Literatura
}

[1] Polóni M., Lach J., Chribik A.: Research and development of combustion engine for micro - cogeneration unit, J. KONES, 19 (2012) 411-422.

[2] Drogosz P., Nitkiewicz S., Piętak A.: The selection of Stirling engines applied to cogeneration systems, J. KONES, 18 (2011)85-90.

[3] Mago P.J., Hueffed A., Chamra L.M.: Analysis and optimization of the use of CHP-ORC systems for small commercial buildings, Energy Buildings, 42 (2010) 1491-1498.

[4] Śnieżyk R.: Warunki techniczne opłacalności systemów kogeneracyjnych, Rynek Energii, 6 (2006) 13-15.

[5] Zaporowski B.: Zgazowanie biomasy w układach kogeneracyjnych małej mocy, Czysta Energia, 2 (2007) 28-29.

[6] Warowny W., Celińska A.: Zgazowanie biomasy, Czysta Energia, 5 (2008) 36-41.

[7] Krzak J.: Układy kogeneracyjne w centralnym systemie ciepłowniczym, Napędy Sterowanie, 11 (2009) 74-76.

[8] Hermansson S., Lind F., Thunman H.: On-line monitoring of fuel moisture-content in biomass-fired furnaces by measuring relative humidity of the flue gases, Chem. Eng. Rerearch Design, 89 (2011) 2470-2476.

[9] Kamiński T.; Kardaś D.: Charakterystyka pomiarowa kotła na biomasę chłodzonego olejem w instalacji ORC, Archiwum Energetyki, 2 (2012) 49-57.

Niniejsza praca powstała dzięki wsparciu funduszu badań statutowych Wydziału Inżynierii Środowiska i Energetyki Politechniki Śląskiej.

\section{INFLUENCE OF BIOMASS MOISTURE CONTENT ON EFFICIENCY OF THERMAL BOILER COMBINED WITH ORC UNIT SYSTEM}

\begin{abstract}
S u m m a r y
Biomass fired thermal oil boilers combined with ORC units are the technology often used for small-scale electricity generators. Such systems use the local biomass, which is usually associated with the variable quality of the biomass, including in particular variable humidity. Simultaneously, the exhaust gas from heat exchanger used for heating the thermal oil has a temperature allowing its using for preheating the combustion air or to preheating the drying air. In the paper energetic effects connected with using flue gas energy for initial preheating of the air used for initial drying of biomass are analysed.
\end{abstract}

Keywords: ORC technology, biomass combustion

DOI: $10.7862 / \mathrm{rm} .2014 .10$

Otrzymano/received: 15.05.2014

Zaakceptowano/accepted: 20.06 .2014 
